\title{
INDIKASI BEDAH KATARAK DI POLIKLINIK MATA BLU RSUP PROF. Dr. R.D. KANDOU MANADO
}

\author{
${ }^{1}$ Charles Indra \\ ${ }^{2}$ Harry J. G. Sumual \\ ${ }^{2}$ Laya M. Rares
}

\author{
${ }^{1}$ Kandidat Skripsi Fakultas Kedokteran Universitas Sam Ratulangi Manado \\ ${ }^{2}$ Bagian Mata Fakultas Kedokteran Universitas Sam Ratulangi Manado \\ Email: charles_huiwei93@yahoo.com
}

\begin{abstract}
According to the World Health Organization (WHO), cataracts are the leading cause of blindness and visual impairment throughout the world. Cataract surgical indications are classified into three groups: 1) visual acuity rehabilitation, 2) medical indications, and 3) cosmetic indications. This study aimed to obtain the indications for cataract surgery at the Ophthalmology Department of Prof. Dr. R.D. Kandou Hospital Manado. This was a descriptive retrospective study. Data were collected from the medical records at the Ophthalmology Department of Prof. Dr. R.D. Kandou Hospital. The results showed that there were 84 cataract patients who underwent cataract surgery from January to June 2012. Based on the indications of cataracts surgery, visual acuity rehabilitation were found in 81 cases (96.43\%) and medical indications in 3 cases $(3.57 \%)$. Conclusion: In these results, it was found that the most cases requiring cataract surgery were in the group: visual acuity rehabilitation. Cosmetic indication was not found in this study.
\end{abstract}

Keywords: cataract, surgery, indication.

\begin{abstract}
Abstrak: Berdasarkan WHO, katarak merupakan penyebab utama kebutaan dan gangguan penglihatan di dunia. Terdapat tiga kelompok indikasi bedah katarak, yaitu: 1) rehabilitasi ketajaman penglihatan, 2) indikasi medis, dan 3) indikasi kosmetik. Penelitian ini bertujuan untuk mengetahui indikasi yang mendorong dilakukannya bedah katarak di Poliklinik Mata BLU RSUP Prof. Dr. R.D. Kandou Manado. Penelitian ini bersifat deskriptif retrospektif dengan menggunakan data dari catatan medis di Poliklinik Mata BLU RSUP Prof. Dr. R.D. Kandou Manado. Hasil penelitian memperlihatkan bahwa terdapat 84 kasus bedah katarak periode Januari-Juni 2012. Berdasarkan indikasi bedah katarak terdapat 81 kasus $(96,43 \%)$ dengan indikasi rehabilitasi ketajaman penglihatan dan 3 kasus $(3,57 \%)$ dengan indikasi medis. Simpulan: Indikasi bedah katarak yang paling sering ditemukan di Poliklinik Mata BLU RSUP Prof. Dr. R.D. Kandou Manado ialah rehabilitasi ketajaman penglihatan. Indikasi kosmetik tidak ditemukan dalam penelitian ini.
\end{abstract}

Kata kunci: katarak, indikasi, bedah.

Lensa mata merupakan struktur globular yang transparan yang terletak di belakang iris dan di depan badan kaca. Bagian depan ditutupi kapsul anterior dan bagian belakang oleh kapsul posterior. Di dalam kapsul terdapat korteks dan nukleus. Lensa tergantung pada zonula Zinni yang melekat pada prosesus siliaris. Fungsi lensa yaitu untuk refraksi dan akomodasi. ${ }^{1}$

Kelainan pada lensa dapat berupa kekeruhan lensa yang disebut katarak. Keadaan ini dapat terjadi sejak saat embrio di dalam kandungan yang terlihat sejak bayi lahir (katarak kongenital). Katarak kongenital dan katarak juvenil disebut juga katarak perkembangan atau pertumbuhan 
karena secara biologik serat lensa masih dalam perkembangannya. Pada usia lanjut, katarak terjadi akibat proses penuaan atau degenerasi (katarak senilis). Kekeruhan lensa juga dapat terjadi akibat penyakit lain (katarak komplikata) atau ruda paksa (katarak trauma). ${ }^{1}$

Berdasarkan WHO, katarak merupakan penyebab utama kebutaan dan gangguan penglihatan didunia. Pada tahun 2002, WHO memperkirakan bahwa katarak yang menyebabkan kebutaan reversibel terjadi pada 17 juta $(47,8 \%)$ dari 37 juta individu buta di dunia, dan jumlah ini diperkirakan mencapai 40 juta pada tahun 2020. WHO menyatakan bahwa diantara tahun 2000 dan 2020, jumlah bedah katarak yang dilakukan di dunia akan mencapai tiga kali lipat agar dapat memenuhi kebutuhan populasi. ${ }^{2}$

Hasil Survei Kesehatan Rumah Tangga Survei Kesehatan Nasional (SKRTSURKESNAS) tahun 2001 menunjukkan prevalensi katarak di Indonesia sebesar 4,9\%. Prevalensi katarak di Jawa dan Bali $(5,5 \%)$ lebih tinggi dibandingkan dengan daerah Indonesia lainnya. Prevalensi katarak di daerah pedesaan $(6,29 \%)$ lebih tinggi dibandingkan daerah perkotaan (4,5\%). Prevalensi katarak di Jawa Barat tahun 1993-1996 sebesar 6,2-9,7\%. ${ }^{3}$

Indikasi bedah katarak dibagi atas tiga kelompok, yaitu: indikasi rehabilitasi ketajaman penglihatan, indikasi medis, dan indikasi kosmetik. Dari ketiga indikasi tersebut, yang paling banyak dijumpai yaitu bedah katarak berdasarkan indikasi rehabilitasi ketajaman penglihatan., ${ }^{4,5}$

\section{METODE PENELITIAN}

Penelitian ini bersifat deskriptif retrospektif dengan menggunakan data dari catatan medis pasien katarak yang menjalani bedah katarak di Poliklinik Mata BLU RSUP Prof. Dr. R.D. Kandou Manado pada bulan Januari-Juni 2012.

Indikasi bedah katarak yaitu indikasi pasien untuk menjalani bedah katarak ditinjau dari indikator rehabilitasi ketajaman penglihatan, medis, dan kosmetik.

\section{HASIL PENELITIAN}

Selama periode Januari-Juni 2012 ditemukan 84 kasus bedah katarak di Poliklinik Mata BLU RSUP Prof. Dr. R.D. Kandou Manado.

Tabel 1 menunjukkan bahwa jumlah pasien katarak yang menjalani bedah katarak dengan indikasi rehabilitasi ketajaman penglihatan paling banyak dilakukan yaitu 81 kasus $(96,43 \%)$.

Tabel 1. Distribusi kasus bedah katarak berdasarkan indikasi bedah katarak.

\begin{tabular}{lcc}
\hline \multicolumn{1}{c}{$\begin{array}{c}\text { Indikasi } \\
\text { bedah katarak }\end{array}$} & Jumlah & \% \\
\hline $\begin{array}{l}\text { Rehabilitasi } \\
\text { ketajaman penglihatan }\end{array}$ & 81 & 96,43 \\
Medis & 3 & 3,57 \\
Total & 84 & 100 \\
\hline
\end{tabular}

Pasien katarak berusia $>50$ tahun yang paling banyak menjalani bedah katarak di BLU RSUP Prof. Dr. R.D. Kandou Manado yaitu 76 kasus $(90,48 \%)$, dengan indikasi rehabilitasi ketajaman penglihatan sebanyak 74 kasus $(88,1 \%)$ dan indikasi medis sebanyak 2 kasus (2,38\%) (Tabel 2).

Tabel 2. Distribusi kasus bedah katarak dengan indikasi bedah katarak berdasarkan usia.

\begin{tabular}{ccccc}
\hline Usia & $\begin{array}{c}\text { Rehabilitasi } \\
\text { ketajaman } \\
\text { penglihatan }\end{array}$ & Medis & $\begin{array}{c}\text { Jum- } \\
\text { lah }\end{array}$ & $\%$ \\
\hline $\begin{array}{c}<20 \\
\text { tahun }\end{array}$ & 0 & 1 & 1 & 1,19 \\
$\begin{array}{c}20-50 \\
\text { tahun } \\
>50\end{array}$ & 7 & 0 & 7 & 8,33 \\
tahun & 74 & 2 & 76 & 90,48 \\
Total & 81 & 3 & 84 & 100 \\
\hline
\end{tabular}

Tabel 3 menunjukkan bahwa berdasarkan jenis kelamin tidak terdapat perbedaan bermakna pada kasus bedah katarak. Indikasi rehabilitasi ketajaman penglihatan lebih sering ditemukan, yaitu 
sebanyak 37 kasus pada laki-laki dan 44 kasus pada perempuan.

Tabel 3. Distribusi kasus bedah katarak dengan indikasi bedah katarak berdasarkan jenis kelamin.

\begin{tabular}{ccccc}
\hline $\begin{array}{c}\text { Jenis } \\
\text { kelamin }\end{array}$ & $\begin{array}{c}\text { Rehabilitasi } \\
\text { ketajaman } \\
\text { penglihatan }\end{array}$ & Medis & $\begin{array}{c}\text { Jum- } \\
\text { lah }\end{array}$ & \% \\
\hline $\begin{array}{c}\text { Laki-laki } \\
\text { Perem- } \\
\text { puan }\end{array}$ & 37 & 2 & 39 & 46,43 \\
Total & 81 & 1 & 45 & 53,57 \\
\hline
\end{tabular}

Tabel 4 menunjukkan bahwa kasus bedah katarak berdasarkan jenis pekerjaan didominasi oleh penderita dengan pekerjaan sebagai ibu rumah tangga sebanyak 31 kasus $(36,90 \%)$ dengan indikasi rehabilitasi ketajaman penglihatan sebanyak 30 kasus $(35,71 \%)$ dan indikasi medis sebanyak 1 kasus $(1,19 \%)$. Namun yang paling sedikit yaitu penderita yang bekerja sebagai buruh dengan jumlah 1 kasus $(1,19 \%)$ dengan indikasi rehabilitasi ketajaman penglihatan.

Tabel 4. Distribusi kasus bedah katarak dengan indikasi bedah katarak berdasarkan pekerjaan.

\begin{tabular}{lcccc}
\hline $\begin{array}{c}\text { Jenis } \\
\text { pekerjaan }\end{array}$ & $\begin{array}{c}\text { Rehabilitasi } \\
\text { tajam } \\
\text { penglihatan }\end{array}$ & Medis Jumlah & \% \\
\hline IRT & 30 & 1 & 31 & 1,19 \\
Buruh & 1 & 0 & 3 & 3,57 \\
PNS & 3 & 0 & 3 & 3,57 \\
Pensiunan & 14 & 0 & 4 & 16,67 \\
Petani & 9 & 0 & 9 & 10,72 \\
Swasta & 3 & 0 & 3 & 3,57 \\
Lain-lain & 21 & 2 & 23 & 27,38 \\
Total & 81 & 3 & 84 & 100 \\
\hline
\end{tabular}

Ket: PNS = Pegawai negeri sipil; IRT $=$ Ibu rumah tangga

\section{BAHASAN}

Jumlah kasus bedah katarak di Poliklinik Mata BLU RSUP Prof. Dr. R.D. Kandou Manado pada periode Januari-Juni 2012 sebanyak 84 orang. Terdapat perbedaan nyata ditinjau dari segi indikasi bedah katarak, usia, dan pekerjaan, namun berdasarkan jenis kelamin tidak berbeda nyata.

Dalam penelitian ini, usia pasien digolongkan atas tiga kategori, yaitu $<20$ tahun (katarak juvenilis), 20-50 tahun (katarak presenilis), dan $>50$ tahun (katarak senilis). ${ }^{5}$ Hasil penelitian inin memperlihatkan bahwa indikasi rehabilitasi ketajaman penglihatan yang paling banyak ditemukan $(96,43 \%)$ dengan diagnosis katarak senilis stadium matur (KSSM), diikuti oleh indikasi medis $(3,57 \%)$ dengan diagnosis katarak traumatika dan nyeri pada mata; indikasi kosmetik tidak dijumpai. Tingginya indikasi rehabilitasi ketajaman penglihatan menunjukkan kesadaran akan pentingnya penglihatan yang jelas, yang berkaitan dengan kualitas hidup. Kanski ${ }^{4}$ juga menyatakan bahwa indikasi rehabilitasi ketajaman penglihatan merupakan indikasi yang paling banyak dijumpai dalam bedah katarak.

Pada penelitian ini, usia pasien bedah katarak yang dominan ialah $>50$ tahun $(90,48 \%)$, sedangkan usia $<20$ tahun yang paing sedikit $(1,19 \%)$. Hal ini sesuai dengan acuan pustaka dari American Academy of Ophthalmology (2008) yang menyatakan bahwa penyebab gangguan penglihatan yang sangat sering pada dewasa tua yaitu katarak berkaitan usia, yang memiliki patogenesis multifaktorial dan tidak secara penuh diketahui. ${ }^{2}$

Pada penelitian ini didapatkan bahwa dari segi jenis kelamin tidak berbeda jauh yaitu laki-laki 39 kasus $(46,43 \%)$ dan perempuan sebanyak 45 kasus $(53,57 \%)$. Penelitian Wahyudi $(2004)^{6}$ di Rumah Sakit William Booth Semarang memperlihatkan hasil yang berbeda yaitu persentase tertinggi pasien katarak pada perempuan (61\%). ${ }^{6}$ Penelitian Saputra (2011) tentang kejadian katarak di Ruang Rekam Medik RSUD Dr. M. Yunus Bengkulu menyatakan bahwa katarak lebih banyak terjadi pada perempuan $(58,34 \%)$. Acuan pustaka dari National Institutes of Health berjudul International Position Paper on Women's Health and Menopause 
(2002) dan Lippincott Williams \& Wilkins berjudul Women's Health: A Guide to Health Promotion and Disorder Management menyatakan bahwa perempuan lebih banyak menderita katarak dimungkinkan karena perubahan hormonal, misalnya penggunaan hormon estrogen, masa kehamilan, dan sebelum/setelah menopause. ${ }^{7}$ Pada penelitian ini, jenis pekerjaan didominasi oleh IRT $(36,90 \%)$ sedangkan yang paling sedikit ialah pekerjaan sebagai buruh $(1,19 \%)$.

\section{SIMPULAN}

Dari hasil penelitian dapat disimpulkan bahwa indikasi bedah katarak yang tersering di Poliklinik Mata BLU RSUP Prof. Dr. R.D. Kandou Manado yaitu rehabilitasi ketajaman penglihatan. Indikasi kosmetik tidak ditemukan dalam penelitian ini.

\section{SARAN}

Disarankan untuk memberikan edukasi kepada masyarakat tentang faktor-faktor risiko yang dapat menyebabkan katarak, sehingga masyarakat dapat memeriksakan diri lebih dini dan perlu dilakukan intervensi dini pada pasien katarak yang imatur, supaya tidak berkembang menjadi katarak matur maupun hipermatur.

\section{UCAPAN TERIMA KASIH}

Ucapan terima kasih ditujukan kepada dr. Herny Poluan, SpM, dan Dr. dr.
Josefien S. M. Saerang, $\operatorname{SpM}(\mathrm{K})$ selaku penguji Skripsi dan kepada semua pihak yang secara langsung atau tidak langsung telah memberikan gagasan dan ide kepada penulis.

\section{DAFTAR PUSTAKA}

1. Ilyas S, Mailangkay H, Taim H, Saman R, Simarmata M, Widodo P. Ilmu Penyakit Mata. Jakarta: CV. Sagung Seto, 2002; p.143-53.

2. American Academy of Ophthalmology. Lens and Cataract. California: American Academy of Ophthalmology, 2008; p.71-89.

3. Tana L, Mihardja L, Rif'ati L. Merokok dan usia sebagai faktor risiko katarak pada pekerja berusia $\geq 30$ tahun di bidang pertanian [homepage on the Internet]. 2007 [cited 2012 Oct 18]. Available from: http://www.univmed. org/wp-content/uploads/2011/02/Lusi1.pdf.

4. Kanski JJ, Bowling B. Clinical Ophthalmology (Seventh Edition). London: Butterworth Heineman, 2007; p.270-3.

5. Wijana N. Ilmu Penyakit Mata. Jakarta: Abadi Tegal, 1989; p.202.

6. Wahyudi D. Hubungan Usia, Jenis Kelamin dan Tingkat Konsumsi Zat Gizi dengan Tingkat Kematangan Katarak Senilis (Studi di Rumah Sakit William Booth Semarang) [Skripsi]. Semarang: FKMUNDIP; 2010.

7. Lippincott Williams \& Wilkins. Women's Health: A Guide to Health Promotion and Disorder Management. USA: Lippincott Williams \& Wilkins, 2005; p.232. 